Research Article

www.ijrap.net (ISSN:2229-3566)

\title{
ROLE OF ANUVASANA BASTI AND KATI BASTI IN THE MANAGEMENT OF GRIDHRASI (SCIATICA)
}

Sarmah J *, Sharma R.K.

Department of Panchakarma, Government Ayurvedic College Guwahati, Assam, India

Received on: 27/04/20 Accepted on: 30/05/20

\author{
*Corresponding author \\ E-mail: drjayantasharma@gmail.com
}

DOI: $10.7897 / 2277-4343.1104108$

\begin{abstract}
Gridhrasi comes under 80 types of Nanatmaja Vatavyadhi, due to its extreme painful condition physician is often called to treat in clinical practice. Symptoms of Gridhrasi resemble with sciatica. The present Clinical study was carried out to assess the effect of Kati Basti and Matra basti in Gridhrasi. In Ayurveda Basti karma is considered as half of the treatment and in Panchakarma Basti is important amongst all the therapy for the management of Vatavyadhi. In this clinical study 20 patients were registered equally divided in to two groups and 10 patients of 1 st group under Kati basti with Dashmoola taila for 14 days and another group of 10 patients received one sitting of Matra basti for two weeks with Sahasradi taila. In this present study of Kati basti group 20\% were cured, $40 \%$ marked improvement, 30\% moderate improvement and 10\% mild improvement and in Matra basti group $40 \%$ patient were cured 30\% got marked improvement and 30\% moderate improvement. None of the patient remained unchanged moreover highly significant result was obtained statistically.
\end{abstract}

Keywords: Gridhrasi, Kati Basti, Matra Basti, Sciatica

\section{INTRODUCTION}

Change of life style is the main cause of sufferings of modern human beings. Most of the individuals are busy with their professional and social life, adopted improper sitting posture, overexertion, jerking movements during travelling and sports becomes part of day to day activity and all this factors produce excess pressure to the spinal cord.

Over $90 \%$ of lumbar disc herniations occur at the $\mathrm{L}_{4-5}$ or $\mathrm{L}_{5}-\mathrm{S}_{1}$ levels. A postero lateral disc protrusion will affect the traversing root, e.g. An $\mathrm{L}_{5}-\mathrm{S}_{1}$ disc protrusion affects the $\mathrm{L}_{5}-\mathrm{S}_{1}$ and affects $\mathrm{S}_{1}$ nerve root. Symptoms typically commence with a period of back pain followed by sciatica leads to paraesthesia, motor weakness, loss of reflexes and reduction in straight leg raise. ${ }^{1}$

Gridhrasi is one of the painful vata vyadhi counted fewer than 80 types of Nanatmaja vata-vyadhi. The characteristic sign and symptoms of Gridhrasi (sciatica) are Ruk (Pain), Toda (pricking sensation), Stambha (stiffness) and Muhuspandana (twisting) in the sphik, kati, uru, janu, jangha and pada in order to sakthikshepa nigraha ${ }^{2}$ i.e. restricted range of motion of lifting of the leg.

In the state of kaphanubandhata some additional symptoms were present like tandra, Gaurava and Arochaka.

According to Ayurveda; healthy does not mean only free from disease, for every individual to be healthy by mentally and spiritually happy. While there is imbalance in doshic equilibrium is termed as Roga. Among tridosha vata is having properties of locomotors its dynamic entity and majority of Vyadhis are due to vatadosha.

Gridhrasi is considered as Vatavyadhi and it is assume that any type of pain cannot be without presence of vata. Due to the nature of severe painful condition of the sufferings involvement of vata in the pathogenesis is clear.
The name of the disease indicates the way of gate shown by the suffering individual due to extreme pain just like Gridhra (vulture), it is clear that the disease is not only infliction of pain but also produce difficulty in walking and sleeping, which is very much frustrating and embarrassing to the patient. The movement of lower limbs get restricted when kandara i.e. ligament of heel and all the toes are affected by vitiated vata. ${ }^{3}$

Panchakarma is a very unique healing procedure due to its preventive and promotive effect. It gives rejuvenation and radical cure. Among this Panchakarma basti karma is such a treatment protocol which can be applicable in all the Vata Vyadhis apart from it basti is equally effective in the treatment of morbid pitta, kapha and rakta. ${ }^{4}$

Matra basti and kati basti procedure are adopted in this clinical study for the management of Gridhrasi.

\section{Objectives}

To evaluate the efficacy of Kati basti with Dashmoola taila and Matra basti with Sahasradi taila in the management of Gridhrasi

\section{MATERIALS AND METHODS}

\section{Source of Data}

Drugs were collected from Rasashala of Government Ayurvedic College, Guwahati, Assam and India. 20 patients of Gridhrasi fulfilling the criteria for inclusion were randomly divided into 2 groups equally from O.P.D. and I.P.D. of Government Ayurvedic College, Guwahati, Assam, India irrespectively of their age, sex, religion etc. 


\section{Diagnostic criteria}

- The improvement in the patients was assessed mainly on the basis of relief in the cardinal symptoms of the disease.

- To assess the effect of therapy objectively, all the sign and symptoms were given scoring pattern depending upon their severity as

- Ruk (Pain)

- Toda (Pricking sensation)

- Stambha (Stiffness)

- Saktnoh Utkshepana Vedana

- Mukhapraseka

- Agnimandya

- Bhaktadosha

- Numbness

- Walking distance

\section{Inclusion criteria}

- Diagnosed cases of Gridhrasi.

- Age between 20-60 yrs.

- Having clinical features of Gridhrasi (Sciatica).

- Fit for Kati Basti and Basti Karma.

\section{Exclusion criteria}

- Age below 20 years and above 60 years.

- Associated with serious illness like

- Carcinoma

- Cardiac Failure

- Malignant Hypertension.

- Not fit for Basti Karma.

\section{Laboratory investigations}

\section{Blood}

Differential leukocyte count, Total leukocyte count, Erythrocyte sedimentation rate, Hemoglobin (gram percentage)

\section{Blood sugar}

X-ray: Anterior, posterior and lateral view of Lumbo- sacral spine

\section{Treatment protocol}

Patients of the $1^{\text {st }}$ group- A were administered kati basti ${ }^{5}$ with Dashmoola taila for two weeks and another group means group B were given Matra basti ${ }^{6}$ with Sahacharadi taila ${ }^{5}$ for two weeks, during this period no internal and external medicine was given except Sthanik abhyanga and Swedana were carried out as the part of Poorvakarma of basti.

Dose of Matra basti: $60 \mathrm{ml}^{7}$

Institutional ethical clearance - IEC/17 20-161; dated: 09/05/2017

\section{Basti schedule}

Apply kati basti a continuous setting for 14 days in group - A. After proper abhyanga and Swedana as a part of Purva karma administered Matra basti every day ${ }^{8}$ for consecutively 14 days in group- B

\section{Assessment criteria}

The assessment of effect of treatment was done on the basis of clinical changes observed in subjective criteria by self-assessment before and after treatment of the patients. Numerical score was assigned for each of the following signs and symptoms:

- Ruk

- Toda

- Stambha

- Numbness

- Aruchi

- Tandra

- Sakthaakshapnigraha (S.L.R. Test )

- Mukhapraseka

- Agnimandya

- Bhaktadwesha

- Tingling sensation

- Burning sensation

- Numbness

- Distance of Walking

\section{Procedure}

\section{A. Kati basti}

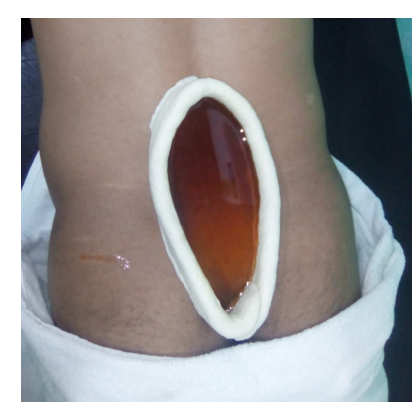

Figure 1: Kati basti 


\section{B. Matra basti}

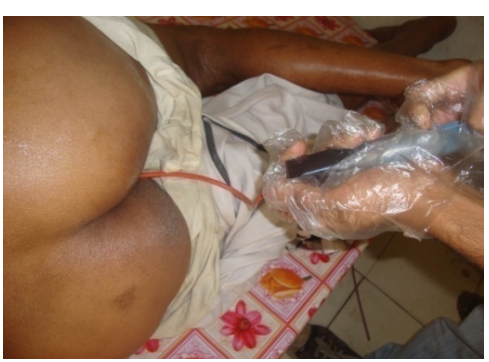

Figure 2: Clinical improvement in the symptoms of Gridhrasi (Sciatica)

\section{RESULT AND DISCUSSION}

Table 1: Effect of Kati basti according to sign and symptoms in group A

\begin{tabular}{|c|c|c|c|c|c|c|c|c|c|}
\hline \multirow[t]{2}{*}{ Sign and symptoms } & \multirow[t]{2}{*}{$\mathbf{N}$} & \multicolumn{2}{|c|}{ Mean score } & \multirow[t]{2}{*}{$\mathbf{X}$} & \multirow[t]{2}{*}{$\%$ Relief } & \multirow[t]{2}{*}{ S.D. } & \multirow[t]{2}{*}{ S.E. } & \multirow[t]{2}{*}{$\mathbf{T}$} & \multirow[t]{2}{*}{$\mathbf{P}$} \\
\hline & & A.T. & B.T. & & & & & & \\
\hline Ruk (pain) & 10 & 3.7 & 0.8 & 2.7 & 75.676 & 0.6325 & 0.2 & 14 & $<.001$ \\
\hline Toda (pricking sensation) & 8 & 3.875 & 0.75 & 3.125 & 80.645 & 0.6409 & 0.2266 & 13.792 & $<.001$ \\
\hline Stambha (stiffness) & 8 & 3 & 1 & 2 & 66.667 & 0.7559 & 0.2673 & 7.4833 & $<.001$ \\
\hline Aruchi (Anorexia) & 2 & 3 & 1.5 & 1.5 & 50 & 0.7071 & 0.5 & 3 & $>.05$ \\
\hline Tandra (Torpor) & 0 & - & - & - & - & - & - & - & - \\
\hline Sakthaahakshepamnigrahaniyat & 10 & 3.5 & 0.8 & 2.7 & 77.143 & 0.8233 & 0.2603 & 10.371 & $<.001$ \\
\hline $\begin{array}{c}\text { Mukhapraseka (Excessive } \\
\text { salivation) }\end{array}$ & 0 & - & - & - & - & - & - & - & - \\
\hline Agni mandya & 2 & 3 & 1.5 & 1.5 & 50 & 0.7071 & 0.5 & 3 & $>.05$ \\
\hline Bhaktadwesha & 0 & - & - & - & - & - & - & - & - \\
\hline Tingling sensation & 7 & 3 & 1 & 2 & 66.667 & 0.8165 & 0.3086 & 6.4807 & $<.001$ \\
\hline Burning sensation & 3 & 3 & 0.6667 & 2.3333 & 77.778 & 1.1547 & 0.6667 & 3.5 & $>.05$ \\
\hline Numbness & 7 & 3 & 0.5714 & 2.4286 & 80.952 & 0.7868 & 0.2974 & 8.1667 & $<.001$ \\
\hline Walking distance & 10 & 2.9 & 0.9 & 2 & 68.966 & 0.4714 & 0.1491 & 13.416 & $<.001$ \\
\hline
\end{tabular}

Table 2: Effect of Matra basti according to sign and symptoms in group B

\begin{tabular}{|c|c|c|c|c|c|c|c|c|c|}
\hline \multirow[t]{2}{*}{ Sign and symptoms } & \multirow[t]{2}{*}{$\mathbf{N}$} & \multicolumn{2}{|c|}{ Mean score } & \multirow[t]{2}{*}{$\mathbf{X}$} & \multirow[t]{2}{*}{ \% Relief } & \multirow[t]{2}{*}{ S.D. } & \multirow[t]{2}{*}{ S.E. } & \multirow[t]{2}{*}{$\mathbf{T}$} & \multirow[t]{2}{*}{$\mathbf{P}$} \\
\hline & & A.T. & B.T. & & & & & & \\
\hline Ruk (pain) & 10 & 2.1 & 0.4 & 1.7 & 80.952 & 0.483 & 0.1528 & 11.129 & $<.001$ \\
\hline Toda (pricking sensation) & 5 & 2 & 0.4 & 1.6 & 80.0 & 0.5477 & 0.2449 & 6.532 & $<.01$ \\
\hline Stambha (stiffness) & 6 & 2 & 0.666 & 1.3333 & 66.667 & 0.5164 & 0.2108 & 6.3246 & $<.01$ \\
\hline Spandan & 8 & 1.75 & 0.375 & 1.375 & 78.571 & 0.5175 & 0.183 & 7.5144 & $<.001$ \\
\hline Aruchi (Anorexia) & 4 & 1.75 & 1.25 & 0.5 & 28.571 & 0.5774 & 0.2887 & 1.7321 & $>.01$ \\
\hline Tandra (Torpor) & 0 & - & - & - & - & - & - & - & - \\
\hline Sakthaahakshepamnigrahaniyat & 10 & 1.7 & 0.4 & 1.3 & 76.471 & 0.483 & 0.1528 & 8.511058 & $<.001$ \\
\hline $\begin{array}{c}\text { Mukhapraseka (Excessive } \\
\text { salivation) }\end{array}$ & 2 & 2 & 0.5 & 1.5 & 75.0 & 0.7071 & 0.5 & 3 & $>0.1$ \\
\hline Agni mandya & 4 & 1.75 & 1.25 & 0.5 & 28.571 & 0.5774 & 0.2887 & 1.7321 & $>0.1$ \\
\hline Bhaktadwesha & 2 & 1 & 1 & 0 & 0 & - & - & - & - \\
\hline Tingling sensation & 8 & 2.125 & 0.625 & 1.5 & 70.588 & 0.5345 & 0.189 & 7.9373 & $<.001$ \\
\hline Burning sensation & 3 & 2.333 & 1 & 1.3333 & 57.143 & 0.5774 & 0.3333 & 4 & $>.05$ \\
\hline Numbness & 8 & 1.875 & 0.5 & 1.375 & 73.333 & 0.5175 & 0.183 & 7.5144 & $<.001$ \\
\hline Walking distance & 10 & 1.7 & 0.6 & 1.1 & 64.706 & 0.3162 & 0.1 & 11 & $<.001$ \\
\hline
\end{tabular}

$\mathrm{N}$ - No of patient, B.T- Before treatment, A.T.- After treatment, S.D.- Standard deviation, S.E.- Standard error

\section{Effect on Signs and Symptoms of Gridhrasi}

Patients of Gridhrasi treated with kati basti showed that $75.676 \%$ relief in the Ruk, $80 \%$ relief in Toda, $66.6673 \%$ relief in Stambha $50.0 \%$ relief in the Aruchi, $77.143 \%$ relief in the SLR, $50 \%$ in Agni mandya, 66.667\% relief in the Tingling sensation, 77.78 in Burning sensation, $80.952 \%$ relief in Numbness and $68.966 \%$ relief in the walking distance.

In group-B where Matra basti introduced in patient of Gridhrasi showed that $80.952 \%$ relief in the Ruk, $80 \%$ relief in Toda, $66.667 \%$ relief in Stambha $78.571 \%$ relief in the Aruchi, $76.47 \%$ relief in the SLR, $76.471 \%$ in Agni mandya, $66.667 \%$ relief in the
Tingling sensation, 77.78 in Burning sensation and 68.966\% relief in the walking distance.

Dashmoola taila Kati Basti which contains roots of 10 drugs among them maximum number dravyas belongs to Ushna veerya; having the Laghu Ruksha Gunas it mainly does Deepana and pachana. Which is indicated in Shula of Jangha, Uru, Pada, and Prusta region and it is indicated in Kapha-avrutta-conditions, it also does Maruta-nigrahana. Sahacharadi Taila which is used for Anuvasana basti containing three drugs among them all are having the Ushna veerya and Kapha-Vata shamaka properties. It is indicated in difficulty in lower limb causing the altered gaits. 


\section{Probable Mode of Action}

Kati basti is a procedure in which both the properties of Snehan and Swedana are incorporated. In comes under direct contact with painful region. As vata is sheeta, ruksha in nature and sweda being ushna and snehanyukta abhyanga is snigdha in nature. Swedana increases sweat and brings out mala dravyas along with sweat. Gridhrasi is a Shoola Pradhana vata vyadhi and shulavyuparama is the sign of proper Swedana. In kati basti the warm oil is retained for a particular time at the site of pathology the resultant effect of the procedure according to the physiology as because vasodilatation due to kati basti increase blood flow to the area and the process of healing is become fast. As we know that basti is the first line of treatment for the vata vyadhi. Basti helps to pacify the vitiated doshas due to its prabhava.

Matra basti is given in a small quantity, it retains in pakwashaya (rectum and colons) and performs it actions in whole body. Rectum is supplied by Haemorrhoidal veins and venous plexus and its vascularity shows good absorbing surface and may soluble substances goes in to the systemic circulation ${ }^{9}$ and colonic drug delivery has gained increased importance not just for the delivery of drugs for the treatment of local disease associated with the colon but also for its potential for the delivery of proteins and therapeutic peptides. Produces there effect within a short period of time. To achieve successful colonic delivery a drug needs to be protected from absorption from upper GIT.

\section{CONCLUSION}

The above clinical trial was carried out to study the effect of kati basti and Matra basti in the management of Gridhrasi. In comparison to the group- A there is significant improvement were observed in most of the sing and symptoms in group- B.

\section{REFERENCES}

1. Short Practice of Surgery by Bailey and Love's, $25^{\text {th }}$ Edition Edited by Norman S. Williams, Christhoper J.K. Bulstrode,
P. Ronan o" Connell. Edward Arnold (Publishers) Ltd; 2008. p. 476.

2. Agnivesha; Charaka Samhita, with Ayurved Dipika Teeka by Chakrapani Dutta, Published by Chaukhamba Sanskrit Sansthan, Varanasi, Fifth edition; p. 696.

3. Sushruta Samhita, Vol II Nidana, Sharir and Chikitsa Sthana, edited by Prof. Vasant C. Patil and Dr. Rajeshwari N.M. First edition, Published by Chaukhamba Publication, New Delhi; 2018. p. 15.

4. Sushruta; Sushruta Samhita with Nibandha Sara Sangraha commentary of Sri Dalhana Acharya and Nyaya Chandrika Panjika of Sri Gayadas Acharya; edited by Vaidya Yadavji Trikamji Acharya and Narayana Ram Acharya. Reprinted edition, 2003, Krishna Das Academy, Varanasi, Uttar Pradesh 6 ${ }^{\text {th }}$ ed; 1997. p. 255, 268, 420-21.

5. Agnivesha; Charaka Samhita, edited by Acharya Vidyadhar Shukla and Prof. Ravi Dutta Tripathi published by Chaukhamba Sanskrit Pratishthan, Delhi, Reprinted; 2011. p. 218.

6. Vagbhata Ashtanga Hridaya, Translated by Prof. KR Srikanta Murthy, Volume I, Published by Chaukhamba Krishnadas Academy, Varanasi; p. 235-239.

7. Vagbhata, Ashtanga Hridaya with the Commentary Sarvanga Sundari and Ayurveda Rasayana Edr. Bhishag Acharya Harishastri Paradakara Vaidya Chaukhamba Orientalia, Varanasi, $8^{\text {th }}$ ed; 1998. p. 276, 416, 418.

8. Sushruta Samhita, Edited by Prof. Vasant C. Patil, Dr. Rajeswari N.M, Vol- II, published by Chaukhamba $1^{\text {st }}$ edition, Publications, New Delhi; 2018. p. 583.

9. National library of Medicine "Pharmaceutical - Approach to colon Targeted Drug Delivery System M.K. Chaurasia et al. J. Pharma Sci. Jan-Apr; 2003.

\section{Cite this article as:}

Sarmah J and Sharma R.K. Role of Anuvasana basti and Kati basti in the management of Gridhrasi (Sciatica). Int. J. Res. Ayurveda Pharm. 2020;11(4):161-164 http://dx.doi.org/10.7897/ 2277-4343.1104108 